\title{
MST1R wt Allele
}

National Cancer Institute

\section{Source}

National Cancer Institute. MST1R wt Allele. NCI Thesaurus. Code C52177.

Human MST 1R wild-type allele is located in the vicinity of 3p21.3 and is approximately 17 $\mathrm{kb}$ in length. This allele, which encodes macrophage-stimulating protein receptor protein, is involved in several biologic processes such as mucociliary function, host defense and fertilization. 